\title{
PENGEMBANGAN PERANGKAT PEMBELAJARAN IPA BIOLOGI BERBASIS MODEL PEMBELAJARAN PEMAKNAAN DALAM PEMBELAJARAN IPA DAN PENUMBUHAN SENSITIVITAS MORAL
}

\author{
IrwanSyah Putra ${ }^{1)}$ \\ Muslimin Ibrahim ${ }^{2)}$ \\ ZA. Imam Supardi ${ }^{3)}$ \\ ${ }^{1}$ Mahasiswa Prodi PendidikanSainsPascasarjanaUniversitasNegeri Surabaya, \\ ${ }^{2}$ Dosen Prodi PendidikanSains Program PascasarjanaUniversitasNegeri Surabaya, \\ ${ }^{3}$ Dosen Prodi PendidikanSains Program PascasarjanaUniversitasNegeri Surabaya \\ e-mail:pirwan40@gmail.com
}

\begin{abstract}
This research aims to develop devices based science learning biology teaching model in an effort to teach the meaning of science and foster moral sensitivity on the subject of human respiratory system. This study was classified as research development, ie developing syllabus, lesson plans, worksheets , BAS, and THB. Follow the development of the design of the 4-D models of Thiagarajan (1974) followed by the implementation phase of learning in the classroom using a pretest - posttest design. Device developed then validated by experts and tested first at 10 eighth grade students of SMP Negeri 1 Tarik. The results showed the validity of the RPP, BAS, and worksheets categorized very well, and the validity of test questions categorized invalid and valid enough. Readability level device includes worksheets for BAS and 77,2\% to the category of material is too easy, and a description of the difficulties include BAS and LKS was $22,1 \%$ with a fairly easy category. The success of RPP during three meetings very well categorized; activity levels of students categorized quite active; better student learning outcomes tests of cognitive abilities , processes, psychomotor and moral sensitivity tests considered complete. Barriers in the PBM especially low student motivation in participating in learning. Based on the analysis of data, it can be concluded that the biology-based science learning learning model of meaning on the subject of the human respiratory system is able to teach science and junior high school students growing moral sensitivity.
\end{abstract}

Key words: The Meaningfull Learning Model, Moral Sensitivity

\begin{abstract}
Abstrak: Penelitian ini bertujuan mengembangkan perangkat pembelajaran IPA Biologi berbasis model pembelajaran pemaknaan sebagai upaya mengajarkan IPA dan menumbuhkan sensitivitas moral pada pokok bahasan Sistem Pernapasan Manusia. Penelitian initergolong penelitian pengembangan, yaitu mengembangkan Silabus, RPP, LKS, BAS, dan THB. Pengembangan perangkat mengikuti rancangan 4-D model dari Thiagarajan (1974) dilanjutkan dengan tahap pelaksanaan pembelajaran di kelas menggunakan rancangan pretest-posttest design. Perangkat yang dikembangkan kemudian divalidasi oleh pakar dan diuji coba I pada 10 siswa kelas VIII SMP Negeri 1 Tarik. Hasil penelitian menunjukkan validitas RPP, BAS, dan LKS berkategori baik; dan validitas soal tes berkategori valid. Tingkat keterbacaan perangkat meliputi BAS dan LKS sebesar 77,2\% dengan kategori materi mudah; dan deskripsi kesulitan perangkat meliputi BAS dan LKS sebesar 22,1\% dengan kategori tidak sulit. Keterlaksanaan RPP selama tiga kali pertemuan berkategori sangat baik; tingkat aktivitas siswa berkategori cukup aktif; hasil tes belajar siswa baik kemampuan kognitif, proses, psikomotor dan tes sensitivitas moral berhasil melampaui KKM yang ditetapkan. Hambatan dalam PBM terutama siswa belum terbiasa dengan model pembelajaran pemaknaan. Berdasarkan hasil analisis data, dapat disimpulkan bahwa perangkat pembelajaran IPA Biologi berbasis model pembelajaran pemaknaan pada pokok bahasan sistem pernapasan manusia efektif membelajarkan IPA dan menumbuhkan sensitivitas moral siswa SMP.
\end{abstract}

Kata-kataKunci:Model Pembelajaran Pemaknaan, Sensitivitas Moral

\section{PENDAHULUAN}

Kemajuan suatu bangsa tergantung pada pengembangan sumber daya manusianya. Pengembangan sumber daya manusia dapat dilakukan melalui jalur pendidikan baik formal maupun nonformal. Peningkatan kualitas sumber daya manusia melalui pendidikan diharapkan dapat mencapai tujuan pendidikan nasional, yang tercantum dalam tiga landasan hukum di Indonesia, yaitu Undang-Undang Dasar 1945, Undang-Undang No. 20 Tahun 2003 tentang Sistem Pendidikan Nasional, dan Peraturan Pemerintah (PP) No. 19 Tahun 2005 tentang Standar Nasional Pendidikan, di antaranya meliputi: 1) Bangsa yang cerdas, damai, merdeka, dan adil; 2)
Memiliki daya saing dalam menghadapi globalisasi; 3) Kualifikasi mencakup sikap, pengetahuan, dan keterampilan. 4) Memiliki dasar kecerdasan, pengetahuan, kepribadian, akhlak mulia, serta keterampilan untuk hidup mandiri dan mengikuti pendidikan lebih lanjut; 5) Memiliki kecakapan hidup mencakup kecakapan pribadi, kecakapan sosial, kecakapan akademik, dan kecakapan vokasional (Ibrahim, 2008:2).

Landasan hukum dalam mewujudkan sumber daya manusia yang berkarakter dan berakhlak mulia tercantum dalam Undang-Undang Dasar RI 1945 pasal 31 ayat 3 yang menyebutkan "Pemerintah mengusahakan 
dan menyelenggarakan satu sistem pendidikan nasional yang meningkatkan keimanan dan ketakwaan serta akhlak mulia dalam rangka mencerdaskan kehidupan bangsa".

Salah satu hasil belajar yang harus dicapai siswa adalah berkembangnya potensi peserta didik secara utuh. Hal ini sesuai dengan Undang-Undang RI No. 20 Tahun 2003 pasal 3 tentang Sistem Pendidikan Nasional yang menyebutkan bahwa pendidikan nasional berfungsi mengembangkan dan membentuk watak serta peradaban bangsa yang bermartabat dalam rangka mencerdaskan kehidupan bangsa, bertujuan untuk berkembangnya potensi peserta didik agar menjadi manusia yang beriman dan bertakwa kepada Tuhan Yang Maha Esa, berakhlak mulia, sehat, berilmu, cakap, kreatif, mandiri, dan menjadi warga negara yang demokratis serta bertanggung jawab (Samani, 2011: 26).

Pendidikan karakter termasuk pencapaian tujuan pembelajaran dalam ranah afektif yang implementasinya dirasakan masih kurang. Hal ini dibuktikan dengan kurangnya perhatian guru dalam menilai hasil belajar afektif. Para guru lebih banyak menilai ranah kognitif semata-mata. Lemahnya pendidikan afektif di sekolah disebabkan sulitnya mengukur tujuan afektif dan merancang pencapaian tujuan pembelajaran afektif. Satuan pendidikan harus merancang kegiatan pembelajaran yang tepat agar tujuan pembelajaran afektif dapat dicapai. Keberhasilan pendidik melaksanakan pembelajaran ranah afektif dan keberhasilan peserta didik mencapai kompetensi afektif perlu diases.

Pendidikan karakter sangat penting diajarkan dan dicontohkan secara sengaja dalam proses pembelajaran di setiap satuan pendidikan. Kenyataan di lapangan bahwa karakter tidak diajarkan secara sengaja dalam pembelajaran, melainkan hanya sebagai efek penyerta saja. Hasil survei yang dilakukan di lapangan (Ibrahim, 2008:4) juga mendukung pendapat di atas. Ada dua hal pokok yang menjadi isu utama di atas: (a) Hasil belajar seperti yang dicantumkan di atas terutama sikap, kepribadian, akhlak mulia serta keterampilan untuk hidup mandiri belum diajarkan secara "sengaja" (by design). Hasil-hasil belajar seperti itu biasanya sebagai efek nurturans (efek penyerta); (b) Proses belajar mengajar belum dilakukan seperti harapan. Pembelajaran masih berpusat pada guru dan siswa sebagai objek, bersifat pasif dan kurang motivasi.

Pengembangan karakter tidak tercapai disebabkan sebagian besar guru selama proses pembelajaran di kelas kurang memberikan tekanan pada nilai-nilai karakter/moral. Pembelajaran dilakukan hanya berlangsung dalam konteks "kulit luar" saja tanpa bisa menyentuh hati dan memaknai apa yang sedang dipelajarinya. Padahal, keshahian pendidikan sepenuhnya merupakan ikhtiar untuk memperoleh nilai hidup, bukan sekedar angka. Jadi pendidikan bukanlah sekedar untuk memperoleh pengetahuan semata, tetapi menghasilkan makna dari setiap pengetahuan yang dipelajarinya. Ukuran dari setiap proses pembelajaran adalah terjadinya pemerolehan makna (Mursidin, 2011:11)

Penerapan model pembelajaran pemaknaan pada mata pelajaran IPA Biologi di SMP diharapkan dapat digunakan untuk menumbuhkan sensitivitas moral siswa yang pada akhirnya akan membentuk karakter siswa tersebut. Dalam IPA terdapat berbagai gejala/fenomena yang amat menarik dan berpotensi untuk menjadi model yang dapat mengajarkan sensitivitas moral, sikap positif dan karakter.

Proses terbentuknya sikap moral melalui penanaman nilai-nilai moral oleh Freud disebut dengan proses internalisasi, sedangkan Blazi menyebutnya proses integrasi (Blazi, 1995). Proses internalisasi moral menurut Rest (1995) diawali oleh peningkatan sensitivitas moral dalam diri seseorang. Sensitivitas moral adalah suatu tingkat kepekaan seseorang akan adanya nilai-nilai moral dalam setiap fenomena yang ada di sekitarnya, atau yang dialami. Jika hal ini diaplikasikan dalam proses pembelajaran, maka sensitivitas moral siswa dapat diketahui dari tingkat kepekaannya akan nilai-nilai moral yang ada pada setiap mata pelajaran, bukan pendidikan moral atau pendidikan agama saja.

\section{METODE PENELITIAN}

Penelitian ini termasuk penelitian pengembangan, karena mengembangkan perangkat pembelajaran dengan model pemaknaan pada materi pokok sistem pernapasan manusia padasiswa SMP kelasVIII. Perangkat yang dikembangkan adalah Silabus, RPP, BAS, LKS, dan THB produk, psikomotor, dan sensitivitas moral.

Pengembangan perangkat dalam penelitian ini menggunakan model 4-D "four D models" (dalam Ibrahim, 2003). Model ini terdiri atas 4 tahap pengembangan, yaitu: Define, Design, Develop, and Disseminate atau diadaptasikan menjadi Model 4-P, yaitu Pendefinisian, Perancangan, Pengembangan, dan Penyebaran. Untuk keperluan guru sendiri, di mana hasil pengembangannya diterapkan di sekolah sendiri, maka tahap keempat yaitu penyebaran belum dilakukan. Maka model 4-P menjadi 3 tahap saja meliputi: (1) Tahap pendefinisian (Define), (2) Tahap perancangan (Design), dan (3) Tahap pengembangan (Develop).

Desain uji coba perangkat pembelajaran dalam pengembangan perangkat ini menggunakan model one Group Pretest-Posttest Design. Sebelum menerapkan pembelajaran dengan model pemaknaan terlebih dahulu dilaksanakan tes awal (pretest) $\mathrm{O}_{1}$, dan setelah 
melaksanakan pembelajaran pemaknaan (X) dilakukan tes akhir (posttest) $\mathrm{O}_{2}$.

Variabel yang diamati dalam penelitian adalah kelayakan perangkat yang terdiri atas: (1) validitas, (2) kepraktisan dan (3) keefektifan. Validitas meliputi: Validitas isi dari Silabus, RPP, BAS, LKS,THB produk, psikomotor, sensitivitas moral, tingkat keterbacaan BAS, tingkat kesulitan BAS. Variabel yang berkaitan dengan kepraktisan hasil uji coba perangkat pembelajaran meliputi: keterlaksanaan RPP, aktivitas siswa, dan hasil belajar siswa. Variabel yang berkaitan dengan keefektifan meliputi: tingkat sensitivitas moral siswa, respon siswa, terhadap pembelajaran dan hambatan dalam penelitian.

Instrumen yang digunakan dalam penelitian ini adalah instrument penilaian perangkat, instrument pengamatan, instrument tes, dan instrument angket. Data yang dianalisis adalah validitas perangkat, kepraktisan perangkat, dan keefektifitas perangkat dengan menggunakan teknik analisis deskriptif kualitatif dan deskriptif kuantitatif.

\section{HASIL DAN PEMBAHASAN}

Penelitian ini dilaksanakan pada 36 siswa Kelas VIII A SMP Negeri 1 Tarik, Sidoarjo, pokok bahasan Sistem Pernapasan Manusia pada semester gasal tahun pelajaran 2013/2014. Adapun hasil validasi dari perangkat yang dikembangkan adalah: (a) Silabus, skor rata-rata 3,84 dengan kategori sangat baik, (b) RPP, skor rata-rata 3,75 dengan kategori sangat baik, (c) BAS, skor rata-rata 3,67 dengan kategori sangat baik, (d) LKS, skor rata-rata 3,78 dengan kategori sangat baik, (e) THB produk, psikomotor berkategori valid, sedangkanTHB sensitivitas moral yang terdiri dari moral knowing, moral feeling, dan moral acting berkategori sangat baik.(f) Tingkat kesulitan BAS sebesar 27\%, sedangkan LKS sebesar 20\%, sehingga tingkat kesulitan rata-rata BAS dan LKS sebesar 23,5\%. Menurut (Rudolph 1948, dan Robert 1944 dalam http://readbulityformula.com/freereadbulity-formula-assessment.php),persentase tingkat kesulitan LKS dan BAS berkategori cukup mudah karena berada pada level 20\% sampai 30\%. (g) Tingkat keterbacaan BAS sebesar 74\%, sedangkan LKS sebesar $66 \%$, sehingga tingkat keterbacaan rata-rata BAS dan LKS sebesar 70\%. Menurut (Taylor 1953, dalamhttp://english.byu.edu/novelink/reading\%20strategi es/Anthem/cloze\%20general.htm),persentase keterbacaan dari hasil perangkat pembelajaran menunjukkan level bebas (di atas $60 \%$ ) termasuk dalam kategori materi terlalu mudah.

Diskusi hasil kepraktisan perangkat pembelajaran meliputi:

(a) Pelaksanaan RPP
RPP disusun sesuai dengan jumlah tatap muka untuk proses pembelajaran yaitu tiga kali pertemuan. Setiap pertemuan dalam PBM pelaksanaan RPP diamati oleh dua pengamat yang mengamati berlangsungnya proses pembelajaran. Persentase rata-rata pelaksanaan RPP pada pertemuan pertama sebesar 93\% dengan reliabilitas 0,90 , persentase rata-rata pelaksanaan RPP pada pertemuan kedua sebesar 93\% dengan reliabilitas 0,90, dan persentase rata-rata pelaksanaan RPP pertemuan ketiga sebesar $100 \%$ dengan reliabilitas 1,00 . Hasil pengamatan dari kedua pengamat berdasarkan nilai rata-rata tentang keterlaksanaan pembelajaran pada ketiga RPP dikategorikan sangat baik.Keterlaksanaan sintaks pembelajaran yang baik ini didukung dengan pola guru mengajar yang tercermin dalam tingkah laku pada waktu melaksanakan pengajaran (Ali, 2000). Pola mengajar dikenal dengan istilah gaya mengajar yang mencerminkan bagaimana pelaksanaan guru yang bersangkutan, yang dipengaruhi oleh pandangannya sendiri tentang mengajar, konsep-konsep psikologi yang digunakan, serta kurikulum yang dilaksanakan.

(b) Aktivitas siswa

Hasil pengamatan terhadap aktivitas siswa selama kegiatan belajar mengajar dinyatakan dalam bentuk angka atau dikuantitatifkan. Aktivitas siswa yang diamati meliputi membaca, mendiskusikan tugas, mencatat, mendengarkan penjelasan guru, melakukan pengamatan, eksperimen atau bekerja, bertanya kepada guru, menyampaikan pendapat atau informasi ke depan kelas, serta perilaku yang tidak relevan.

Tabel 3.1 Aktivitas Siswa dalam Pembelajaran

\begin{tabular}{|c|c|c|c|c|c|}
\hline \multirow[t]{2}{*}{ No } & \multirow[t]{2}{*}{$\begin{array}{c}\text { Aktivitas yang } \\
\text { Diamati }\end{array}$} & \multicolumn{3}{|c|}{$\begin{array}{c}\text { Rata-rata } \\
\text { Persentase } \\
\text { Aktivitas }\end{array}$} & \multirow[t]{2}{*}{$\begin{array}{c}\text { Rata- } \\
\text { rata } \\
(\%)\end{array}$} \\
\hline & & $\begin{array}{c}\text { Prt } \\
1\end{array}$ & $\begin{array}{c}\text { Prt } \\
2\end{array}$ & $\begin{array}{c}\text { Prt } \\
3\end{array}$ & \\
\hline 1. & Membaca. & 15 & 14,5 & 14,4 & 14,6 \\
\hline 2. & $\begin{array}{l}\text { Mendiskusikan } \\
\text { tugas }\end{array}$ & 14 & 13,7 & 13,6 & 13,8 \\
\hline 3. & Mencatat & 14,6 & 12,9 & 14,6 & 14 \\
\hline 4. & $\begin{array}{l}\text { Mendengarkan } \\
\text { penjelasan guru }\end{array}$ & 10,7 & 11,4 & 11 & 11 \\
\hline 5. & $\begin{array}{l}\text { Melakukan } \\
\text { eksperimen }\end{array}$ & 16,4 & 16,5 & 15,3 & 16,1 \\
\hline 6. & $\begin{array}{l}\text { Bertanya kepada } \\
\text { guru }\end{array}$ & 14,3 & 14,8 & 14,4 & 14,7 \\
\hline 7. & $\begin{array}{l}\text { Mengkomunikasika } \\
\mathrm{n} \text { informasi }\end{array}$ & 13,4 & 14,9 & 15,2 & 14,6 \\
\hline 8 & $\begin{array}{l}\text { Aktivitas tidak } \\
\text { relevan }\end{array}$ & 1,6 & 1,3 & 1,5 & 1,5 \\
\hline
\end{tabular}

Berdasarkan Tabel 3.1 di atas, dapat diketahui bahwa rata-rata persentase aktivitas siswa yang relevan sebesar 
98,5\% dengan kategori aktif, sedangkan rata-rata persentase aktivitas siswa yang tidak relevan sebesar 1,5\%. Hal ini berarti secara keseluruhan siswa beraktivitas relevan selama pembelajaran berlangsung dan pembelajaran lebih berpusat pada siswa ( student center). Hal ini sesuai dengan pendapat Ibrahim (2008) bahwa salah satu prinsip model pembelajaran pemaknaan adalah student center.

(c) Ketuntasan hasil belajar siswa

Ketuntasan hasil belajar siswadapat diamati dari grafik dibawah ini:

Gambar 3.1 Grafik Ketuntasan Hasil Belajar Siswa

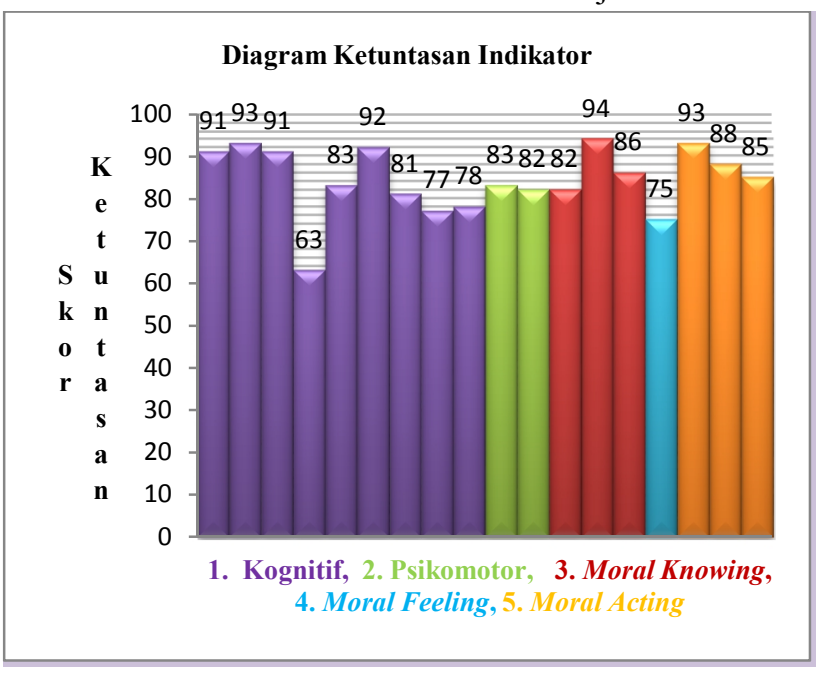

Berdasarkan Gambar 3.1 ketuntasan hasil belajar siswa diperoleh berdasarkan tingkat ketuntasan indikator pada materi sistem pernapasan manusia. Terdapat 18 indikator, 17 indikator dinyatakan tuntas, dan hanya satu indikator yang tidak tuntas, yaitu indikator keempat dari THB kognitif PG. Rata-rata ketuntasan indikator mencapai 84.

Diskusi hasil keefektifan perangkat pembelajaran meliputi: (a) Tingkat sensitivitas moral siswa; (b) Respon siswa terhadap pembelajaran (c) Hambatanhambatan penelitian.

(a) Tingkat sensitivitas moral

Tingkat sensitivitas moral siswa diukur dengan THB moral knowing, moral feeling, dan moral acting.

1. THB pengetahuan moral (moral knowing) digunakan untuk mengetahui pengetahuan siswa tentang nilai-nilai moral terkait konsep sistem pernapasan manusia.Data dan analisis THB pengetahuan moral (moral knowing) siswa dapat dilihat pada Tabel 3.2 berikut ini.

Tabel 3.2 Ketuntasan THB moral knowing

\begin{tabular}{|c|c|c|c|c|c|}
\hline \multirow{2}{*}{ TP } & \multicolumn{2}{|c|}{$\begin{array}{c}\text { Proporsi } \\
\text { Butir Soal }\end{array}$} & $\begin{array}{c}\text { Sensi } \\
\text { Tivitas }\end{array}$ & pTP & Ket \\
\cline { 2 - 5 } & U1 & U2 & & & \\
\hline 8.1 & 0,60 & 0,90 & 0,30 & 0,90 & Tuntas \\
\hline 8.2 & 0,54 & 0,92 & 0,38 & 0,92 & Tuntas \\
\hline 9.1 & 0,58 & 0,94 & 0,36 & 0,94 & Tuntas \\
\hline 9.2 & 0,52 & 0,91 & 0,39 & 0,91 & Tuntas \\
\hline 8.1 & 0,63 & 0,95 & 0,32 & 0,95 & Tuntas \\
\hline
\end{tabular}

\begin{tabular}{|l|l|l|l|l|l|}
\hline 8.2 & 0,54 & 0,93 & 0,39 & 0,93 & Tuntas \\
\hline 5.1 & 0,61 & 0,93 & 0,32 & 0,93 & Tuntas \\
\hline
\end{tabular}

Berdasarkan Tabel 3.2 diperoleh hasil THB pengetahuan moral (moral knowing) siswa dari ketujuh tujuan pembelajaran semuanya tuntas. Rata-rata proporsi tujuan pembelajaran sebesar 0,92. Sensitivitas butir soal pada THB pengetahuan moral (moral knowing) siswa dari ketujuh butir soal yang ada, semua sensitif dengan rata-rata sensitivitasnya sebesar 0,35 .

2. THB perasaan moral (moral feeling) siswa diperoleh dari hasil penilaian laporan diri siswa. Laporan diri siswa digunakan untuk mengetahui penilaian, perasaan, emosi, visi, dan misi siswa terkait konsep sistem pernapasan manusia.Data dan analisis THB perasaan moral (moral feeling) siswa dapat dilihat pada Tabel 3.3 berikut ini.

Tabel 3.3 Ketuntasan THB moral feeling

\begin{tabular}{|c|c|c|c|c|c|c|}
\hline \multirow[t]{2}{*}{ TP } & \multirow[t]{2}{*}{ Aspek } & \multicolumn{2}{|c|}{$\begin{array}{c}\text { Proporsi } \\
\text { Butir Soal }\end{array}$} & \multirow[t]{2}{*}{$\begin{array}{c}\text { Sensi } \\
\text { tivitas }\end{array}$} & \multirow[t]{2}{*}{$\begin{array}{c}\mathbf{p} \\
\mathbf{T P}\end{array}$} & \multirow[t]{2}{*}{ Ket. } \\
\hline & & U1 & $\mathrm{U} 2$ & & & \\
\hline \multirow{3}{*}{3.2} & Menilai & 0,44 & 0,93 & 0,49 & 0,93 & Tuntas \\
\hline & Visi & 0,42 & 0,90 & 0,48 & 0,90 & Tuntas \\
\hline & Misi & 0,41 & 0,82 & 0,41 & 0,82 & Tuntas \\
\hline
\end{tabular}

Tabel 3.3 memperlihatkan bahwa THB perasaan moral (moral feeling) dinyatakan tuntas. Rata-rata proporsi tujuan pembelajaran sebesar 0,88. Sensitivitas butir soal pada THB perasaan moral (moral feeling) siswa, dari 3 butir soal yang ada semua sensitif karena nilainya di atas 0,30 .

3. THB tindakan moral (moral acting) digunakan untuk mengetahui kemajuan siswa dalam hal keterampilan sosial yang meliputi aspek 1) tanggung jawab, 2) peduli sosial, 3) sensitivitas moral. Ketuntasan dan Sensitivitas THB tindakan moral (moral acting)siswa dapat dilihat pada Tabel 3.4 berikut ini.

Tabel 3.4 Ketuntasan THB moral acting

\begin{tabular}{|c|c|c|c|c|c|c|}
\hline \multirow[t]{2}{*}{ TP } & \multirow[t]{2}{*}{ Topik } & \multicolumn{2}{|c|}{$\begin{array}{l}\text { Proporsi } \\
\text { Butir Soal }\end{array}$} & \multirow{2}{*}{$\begin{array}{l}\text { Sensi } \\
\text { tivitas }\end{array}$} & \multirow{2}{*}{$\underset{\text { TP }}{\mathbf{p}}$} & \multirow[t]{2}{*}{ Ket } \\
\hline & & U1 & U2 & & & \\
\hline \multirow{3}{*}{$\begin{array}{l}6.1 \\
6.1 \\
2.1\end{array}$} & $\begin{array}{c}\text { Tanggung } \\
\text { jawab }\end{array}$ & 0,49 & 0,81 & 0,32 & 0,81 & Tuntas \\
\hline & $\begin{array}{l}\text { Peduli } \\
\text { Sosial }\end{array}$ & 0,50 & 0,86 & 0,36 & 0,86 & Tuntas \\
\hline & $\begin{array}{c}\text { Sensitivita } \\
\text { s Moral }\end{array}$ & 0,51 & 0,88 & 0,37 & 0,88 & Tuntas \\
\hline
\end{tabular}

Tabel 3.4 memperlihatkan bahwa THB tindakan moral (moral acting) dari tiga Tujuan Pembelajaran (TP) dinyatakan tuntas. Rata-rata proporsi tujuan pembelajaran sebesar 0,85. Sensitivitas butir soal pada THB tindakan moral (moral acting) siswa berada pada rentang 0,320,37. Butir soal THB tindakan moral (moral acting) semuanya berkategori sensitif karena nilai sensitivitasnya di atas 0,30 . 
(b) Respon siswa terhadap Pembelajaran

Deskripsi respon siswa terhadap pembelajaran dengan model pemaknaan dalam pembelajaran IPA dan penumbuhan sensitivitas moraldiperoleh berdasarkan rekapitulasi hasil angket respon siswa. Hasil analisis respon siswa terhadap model pembelajaran pemaknaan pada kelas penelitian dapat diuraikan pada Tabel 3.5 berikut ini.

Tabel 3.5 Respon Siswa Terhadap Pembelajaran

\begin{tabular}{|c|c|c|c|}
\hline \multirow[t]{2}{*}{ No } & \multirow[t]{2}{*}{ Uraian Pertanyaan } & \multicolumn{2}{|c|}{$\begin{array}{c}\text { Respon } \\
\text { Penilaian (\%) }\end{array}$} \\
\hline & & $(+)$ & $(-)$ \\
\hline 1. & $\begin{array}{l}\text { Respon tertarik } \quad \text { pada } \\
\text { materi,BAS, LKS, Fase pemaknaan }\end{array}$ & 89 & 11 \\
\hline 2. & $\begin{array}{l}\text { Respon baru pada materi, BAS, } \\
\text { LKS, Fase pemaknaan, LP. } \\
\text { Psikomotor }\end{array}$ & 87 & 13 \\
\hline 3. & $\begin{array}{l}\text { Respon mudah pada bahasa BAS, } \\
\text { materi dan LKS }\end{array}$ & 92,4 & 7,6 \\
\hline 4. & $\begin{array}{l}\text { Respon mudah mengikuti sintaks } \\
\text { pemaknaan }\end{array}$ & 85,5 & 14,5 \\
\hline 5. & $\begin{array}{l}\text { Respon berminat pada } \\
\text { model pemaknaan }\end{array}$ & 88 & 12 \\
\hline 6. & Respon kejelasan pada kegiatan & 97 & 3 \\
\hline 7. & $\begin{array}{l}\text { Respon mudah pada THB kognitif, } \\
\text { psikomotor, afektif }\end{array}$ & 92 & 8 \\
\hline 8. & $\begin{array}{l}\text { Respon baru pada THB kognitif, } \\
\text { psikomotor, afektif }\end{array}$ & 94 & 6 \\
\hline
\end{tabular}

Data pada Tabel 3.5 menunjukkan bahwa respon siswa dalam pembelajaran IPA dengan model pembelajaran pemaknaan mendapatkan respon positif.

(c) Hambatan-hambatanpenelitian

Hambatan yang dihadapi selama proses pembelajaran berlangsung diantaranya, siswa belum terbiasa dengan model pembelajaran pemaknaan, keterbatasan alat dan bahan yang digunakan dalam praktikum, yang kesemuanya berpengaruh terhadap proses pembelajaran pada penelitian ini. Solusi untuk hambatan berupasiswa belum terbiasa dengan model pembelajaran pemaknaan adalah dengan membiasakan siswa dengan sintaks model pembelajaran pemaknaan. Demikian juga dengan keterbatasan alat dan bahan yang digunakan dalam praktikum dapat diatasi dengan mengusahakan alat dan bahan yang belum lengkap. Menurut Purwanto (2002), berhasil atau tidaknya belajar dipengaruhi oleh berbagai macam faktor yang dibedakan menjadi faktor individual dan faktor sosial. Salah satu faktor sosial yang mempengaruhi proses belajar adalah alat-alat yang digunakan dalam belajar mengajar. Sekolah yang memiliki peralatan dan perlengkapan yang diperlukan akan mempermudah dan mempercepat belajar anak-anak.

\section{PENUTUP}

\section{Simpulan}

Berdasarkan hasil dan diskusi yang telah diuraikan, maka dapat ditarik simpulan bahwa pengembangan perangkat pembelajaran IPA Biologi berbasis model pembelajaran pemaknaan pada materi pokok Sistem Pernapasan Manusia efektif dalam membelajarkan IPA dan menumbuhkan sensitivitas moral siswa SMP.

\section{Saran}

Berdasarkan penelitian yang telah dilakukan, peneliti memberikan saran-saran sebagai berikut:

1. Berdasarkan proses internalisasi moral, kesensitifan seseorang akan nilai moral terhadap fenomena di sekitarnya sebenarnya tahap awal bagi penanaman moral dalam diri seseorang. Tahap-tahap yang lain adalah keputusan moral, motif moral, dan aplikasi moral. Diperlukan penelitian yang mendalam mengenai potensi model pembelajaran pemaknaan untuk mengajarkan aspek-aspek moral yang lainnya.

2. Peneliti menyarankan untuk lebih mendalam ipotensi model pembelajaran pemaknaan untuk mengajarkan nilai-nilai lainnya seperti budipekerti, sikap positif, serta akhlakul karimah.

\section{DAFTAR PUSTAKA}

Ali, Muhammad. 2004. Guru dalam Proses Mengajar. Bandung: Penerbit Sinar Baru Algesindo.

Arends, I. Richard. 1997. Learning to Teach. New York: Mc. Graw Hill Companies, Inc.

Blazi, Augusto. 1995. Moral Integration. DalamKurtines, W.M. \&Gewirtz, J.L. Moral Development, an Introduction. Needham Heights: A Simons and Schuster Company.

Ibrahim, Muslimin. 2008. Model Pembelajaran IPA InovatifmelaluiPemaknaan. Surabaya: Depdiknas Balitbang.

Mursidin. 2011. Moral Sumber Pendidikan. Bogor: Ghalia Indonesia.

Purwanto, Ngalim. 2002. Ilmu Pendidikan Teoretis dan Praktis. Bandung: PT Remaja Rosdakarya.

Rest, James. 1995. The Four Components of Acting Morally. dalamKurtines, W.M. \&Gewirtz, J.L. Moral Development, an Introduction. Needham Heights: A Simons and Schuster Company.

Samani, M dan Hariyanto. 2011. Konsep dan Model Pendidikan Karakter. Bandung: PT Remaja Rosdakarya.

Taylor,W. 1953. Cloze Prosedure. Dalam http://english.byu.edu/novelinks/reading\%20strategi es/anthemcloze\%20general.htm). 
Tiagarajan, S., Dorothy S.Semmel \& M.I, Semmel. 1974. Instructional Development for Training Center of Expectional Children. Blomington: Center for Innovation on Teaching The Handicapped. http://readbulityformula.com/free-readbulity formula-assessment.php, diakses pada tanggal 6 Nopember 2013). 